\title{
Silage microbiology and its control through additives
}

\author{
Richard E. Muck ${ }^{1}$ \\ ${ }^{1}$ U.S. Department of Agriculture, Agricultural Research Service - U.S. Dairy Forage Research Center, Madison, WI.
}

ABSTRACT - Ensiling is a method of preserving a moist crop. A moist crop can support the growth of a wide range of microorganisms, most of which will degrade the nutrient value to livestock. However, ensiling generally controls microbial activity by a combination of an anaerobic environment and a natural fermentation of sugars by lactic acid bacteria on the crop. This fermentation and the resulting low $\mathrm{pH}$ primarily suppress the growth of other anaerobic microorganisms. The fermentation can also inhibit yeasts, molds and aerobic bacteria, but the anaerobic environment is essential to preventing most of the spoilage microorganisms from growing. Inoculants have become the dominant additives for making silage. Homofermentative strains help guarantee a rapid suppression of anaerobic stains early in storage, increase dry matter recovery and have improved animal performance by means that we do not fully understand. Inoculants containing Lactobacillus buchneri, a heterofermentative species capable of fermenting lactic acid to acetic, are recent additives. The added acetic acid inhibits yeast and mold growth, increasing aerobic stability of silages at feeding.

Key Words: clostridia, enterobacteria, inoculant, lactic acid bacteria, mold, yeast

\section{Microbiologia da silagem e seu controle com aditivos}

RESUMO - Ensilagem é um método de preservação de uma cultura úmida. Uma cultura úmida pode favorecer o crescimento de vários tipos de microrganismos, sendo que a maioria pode degradar o valor nutricional do alimento para o gado. No entanto, a ensilagem geralmente controla a atividade microbiana pela combinação de um ambiente anaeróbio com a fermentação natural dos açúcares por bactérias do ácido lático presentes na cultura. Essa fermentação e a consequente redução do $\mathrm{pH}$ suprimem principalmente o crescimento de outros microrganismos anaeróbios. A fermentação também pode inibir leveduras, fungos filamentosos e bactérias aeróbias, mas o ambiente anaeróbio é essencial para prevenir o crescimento da maioria dos microrganismos deterioradores. Inoculantes tornaram-se os aditivos dominantes para a produção de silagem. Estirpes homofermentativas ajudam a garantir uma rápida supressão das estirpes anaeróbias durante o início de armazenamento, aumentam a recuperação de matéria seca e melhoram o desempenho animal por meio de mecanismos que nós não entendemos completamente. Inoculantes contendo Lactobacillus buchneri, uma espécie heterofermentativa capaz de fermentar o ácido lático a ácido acético, são aditivos recentes. O ácido acético inibe o crescimento de leveduras e fungos filamentosos, aumentando a estabilidade aeróbia de silagens na alimentação.

Palavras-chave: bactérias lácticas, bolores, clostrídios, enterobactérias, inoculante, leveduras

\section{Introduction}

A moist crop can support the growth of a wide range of microorganisms, most of which will degrade the crop's nutrient value to livestock. However, ensiling generally controls microbial activity by a combination of an anaerobic environment and a natural fermentation of sugars by lactic acid bacteria on the crop.

It is important to understand both the microorganisms that are present on the crop at ensiling and how ensiling preserves the crop, inhibiting detrimental microorganisms. Today, there is also a wide range of microbial additives to aid in preservation. It is equally important to know how they alter silage fermentation, preservation, and utilization by livestock. This paper will review these areas briefly.

Silage microbiology

The crop at ensiling contains both aerobic and anaerobic microorganisms and a range of both bacteria and fungi that affect silage quality. Typical classes of microorganisms and the range of their populations at ensiling are shown in Table 1. As would be expected, the dominant populations are aerobic microorganisms or facultative aerobes. Often the lactic acid bacteria that we depend upon to preserve the crop are orders of magnitude lower in population than other groups of microorganisms on the crop at ensiling. 
Table 1 - Typical populations of bacterial and fungal groups on plants prior to ensiling (Pahlow et al., 2003)

\begin{tabular}{lc}
\hline Group & $\begin{array}{c}\text { Population } \\
\text { (colony-forming units/g crop) }\end{array}$ \\
\hline Total aerobic bacteria & $>10,000,000$ \\
Lactic acid bacteria & $10-1,000,000$ \\
Enterobacteria & $1000-1,000,000$ \\
Yeasts and yeast-like fungi & $1000-100,000$ \\
Molds & $1000-10,000$ \\
Clostridia (endospores) & $100-1,000$ \\
Bacilli (endospores) & $100-1,000$ \\
Acetic acid bacteria & $100-1,000$ \\
Propionic acid bacteria & $10-1,000$ \\
\hline
\end{tabular}

\section{Lactic acid bacteria}

The term, lactic acid bacteria, covers bacteria from a number of genuses (Lactobacillus, Pediococcus, Lactococcus, Enterococcus, Streptococcus and Leuconostoc) that are found in silage (Pahlow et al., 2003). They all produce lactic acid as their principal product from fermenting sugars, but other products, particularly acetic acid, ethanol and carbon dioxide, are common. They have been commonly grouped into homofermenters and heterofermenters by the products of fermenting glucose. The homofermenters produce 2 moles of lactic acid from one mole of glucose. The heterofermenters produce one mole of lactic acid, one mole of carbon dioxide and either one mole of ethanol or one mole of acetic acid from glucose. Today, there are three groups of lactic acid bacteria: obligate homofermenters that are unable to ferment pentoses because they lack phosphoketolase, facultative heterofermenters that ferment hexoses like the obligate homofermenters but are able to ferment pentoses, and obligate heterofermenters that ferment hexoses to a range of products. Most lactic acid bacteria in silage fall into the latter two categories.

The lactic acid bacteria generally need various amino acids and vitamins for growth (Pahlow et al., 2003). Yet in spite of their complex requirements, they dominate the fermentation of crops in the silo once anaerobic conditions are established. How exactly this occurs is not understood, but lactic acid bacteria have several mechanisms that might explain their dominance. First, many can grow in aerobic conditions and a common endproduct of their activity under aerobic conditions is hydrogen peroxide (Condon, 1987), which can kill other microorgansisms and in some cases accumulate sufficiently to inhibit the lactic acid bacteria too. Various strains of lactic acid bacteria produce bacteriocins that can inhibit other microorganisms (Gollop, et al., 2005). However, their dominance may not be due to either of these factors. For example, various lactic acid bacterial inoculants do not or are not known to produce bacteriocins (Gollop et al., 2005) and yet are effective in dominating fermentation. So their dominance may only depend on rapid growth under anaerobic conditions. Yeasts

Yeasts are perhaps the most significant aerobic microorganisms on the crop relative to silage quality. Yeasts grow on soluble substrates, sugars and lactic acid being the most important relative to silage. In most circumstances, yeasts are the first group of microorganisms to develop once oxygen comes in contact with silage, either during storage or during feed out. The reason for this is that many yeasts are capable of growing at $\mathrm{pH} 3.5$, well below the $\mathrm{pH}$ of most silages. Acetic acid bacteria and molds are capable of growing under such acidic conditions, but acetic acid bacteria are rarely present and molds grow much more slowly than yeasts. As yeast species that can utilize lactic acid aerobically develop, $\mathrm{pH}$ increases in the silage. This opens the way for the growth of other spoilage (aerobic) microorganisms, particularly once $\mathrm{pH}$ is above 4.5 .

Yeasts are also important because some species can grow anaerobically, fermenting sugars to ethanol. When silages have substantial levels of sugars remaining after the lactic acid bacteria are inhibited by low $\mathrm{pH}$, yeasts may develop and are the presumed cause of most high ethanol silages ( $>20 \mathrm{~g} / \mathrm{kg}$ dry matter [DM]). Certainly this would be a concern in your sugar cane silages. Some of the fermentative yeasts are active aerobically whereas others grow but slowly. So a high ethanol silage can be highly variable in terms of aerobic stability.

Molds

Molds are the filamentous fungi present on the crop. These microorganisms are strictly aerobic. By comparison with other microorganisms in silage, they are on average the slowest growers. While they can grow on a wide variety of compounds, they rarely are apparent or at sufficient population to affect gross measures of silage quality until the silage has undergone substantial aerobic deterioration by yeasts and various aerobic bacteria. So their visual presence is an indication of silage that is of considerably lower quality than the crop at ensiling.

Molds are also of concern because of their production of mycotoxins. An adequate discussion of mycotoxins could constitute a separate review on its own. Mycotoxins are generally produced under stress conditions for the molds, and the environmental stressors that initiate mycotoxin production vary widely across species. Mycotoxins are not a serious issue relative to the preservation of the crop in the silo, but are of concern relative to the health of livestock eating the contaminated 
silage. With very good management, mycotoxin concentrations in silage are generally similar to those present on the crop at ensiling. The development of mycotoxins in the silo is an indication of excessive oxygen exposure.

\section{Acetic acid bacteria}

Acetic acid bacteria are aerobic bacteria that are capable of growing at low $\mathrm{pH}$. They grow on ethanol, producing acetic acid. However, once ethanol has been exhausted, they can grow on acetic acid, producing carbon dioxide and water. This will raise $\mathrm{pH}$ and permit other aerobic microorganisms to grow. Consequently, acetic acid bacteria can be initiators of aerobic deterioration. At present, acetic acid bacteria have only been reported in corn silage, silage that usually has a low buffering capacity so that lactic and acetic acid concentrations are low and a high sugar content that could permit high ethanol concentrations. They have not been found in C3 grass silages or legume silages. Sugar cane silages and perhaps other similar C4 grass silages may be candidate silages to look for acetic acid bacteria, i.e., crops with characteristics similar to corn.

\section{Bacilli}

There are two major groups of bacteria that can be active aerobically and anaerobically, bacilli and enterobacteria. Some bacilli can ferment sugars and organic acids in the silo. However, their activity under anaerobic conditions is considered to be of relatively rare importance. Their more significant activity is in advancing the spoilage of silage when exposed to oxygen. After yeasts or acetic acid bacteria have raised $\mathrm{pH}$ (approximately 4.5 or above), and temperature has increased modestly $\left(40^{\circ} \mathrm{C}\right)$, a second wave of heating usually occurs with temperatures rising to $50^{\circ} \mathrm{C}$ or higher. This often is the activity of bacilli (Muck \& Pitt, 1994), producing a silage that has a slimy feel.

\section{Enterobacteria}

In contrast to the bacilli, the primary effects of the enterobacteria, facultative anaerobes, on silage comes under anaerobic conditions. Various species of enterobacteria can use nitrate as an electron acceptor in place of oxygen, reducing nitrate to nitrite or nitrogen oxide. These bacteria are the principal source of silo gas (a mixture of various $\mathrm{NO}_{\mathrm{x}}$ gases) emanating from silos.

Enterobacteria are also the principal competitors of the lactic acid bacteria for the sugars in the crop. Their principal fermentation product is acetic acid, not lactic. Other fermentation products in silage that are signs of their presence are succinic acid and 2,3-butanediol. As a consequence, their fermentation is less desirable than that of lactic acid bacteria.
Finally some enterobacteria may produce endotoxins in silage. Little is really known about production in the silo. Anecdotally, high acetic acid silages with no butyric acid have been associated with poor intake. We do know that high acetic acid silage produced by Lactobacillus buchneri treatment has not reduced intake by cattle (Kleinschmit \& Kung, 2006). This suggests that enterobacteria are the cause of the poor intake due to some other compound that they produce, not specifically the acetic acid.

\section{Clostridia}

Clostridia are obligate anaerobes, and their effects on silage quality usually occur long after the lactic acid bacteria have stopped actively growing in the silo. The most important silage species are divided into three groups by the principal compounds they ferment: proteolytic clostridia that ferment amino acids primarily, the Clostridium butyricum group that ferment carbohydrates, and C. tyrobutyricum that ferments some sugars but more importantly ferments lactic acid. The proteolytic clostridia produce various compounds in catabolizing amino acids; the most significant are ammonia, amines and carbon dioxide. The primary products of the $C$. butyricum group and C. tyrobutyricum are butyric acid, acetic acid, hydrogen and carbon dioxide.

Clostridial activity is undesirable for several reasons. First and foremost is the reduced intake by livestock of silages with evidence of substantial clostridial activity (i.e., butyric acid at $>5 \mathrm{~g} / \mathrm{kg} \mathrm{DM}$ ). The cause of the reduced intake is uncertain. It does not appear to be butyric acid, a common acid in the rumen that ruminants routinely taste as they chew their cud. Amines have been associated with reduced intake in small ruminants but not necessarily in cattle. Whatever the cause, the practical realities are that farmers have to reduce the proportion of clostridial silage in a ration as butyric acid increases during storage in order to keep intakes constant. Secondly, lactating dairy cows, particularly those in transition, may be more susceptible to ketosis from the added butyric acid from consuming clostridial silage. Thirdly, the fermentation of lactic acid to butyric acid is one of the most wasteful anaerobic fermentations in silage, producing a $51 \%$ loss of DM and $18 \%$ loss of gross energy (McDonald et al., 1991).

\section{How ensiling preserves a crop}

Most silages are made at a dry matter content between 200 to $500 \mathrm{~g} / \mathrm{kg}$. Within this DM range, many enzymes in the plant are still active at ensiling. Also the wide variety of bacteria, yeasts and molds described above can all grow within this range. So it is a substantial challenge to bring 
all of this biological activity under control, but that is what a well-managed ensiling process does.

There are two key processes that preserve the crop in the silo: the creation of an anaerobic environment and the fermentation of sugars by lactic acid bacteria to lactic acid and other products. Both processes are important to good preservation, and one cannot substitute for the other.

The main process that we associate with ensiling is the fermentation of sugars by lactic acid bacteria. Once the crop is anaerobic, lactic acid bacteria grow rapidly and quickly become, in most cases, the dominant microorganisms on the crop. They ferment sugars mainly to lactic acid, acetic acid, ethanol and carbon dioxide. The ratio of products depends upon the species. Typical fermentation reactions are shown in Table 2. Assuming a mix of hetero- and homofermentative lactic acid bacteria, lactic acid will be the dominant product on a molar basis followed in descending order by carbon dioxide, acetic acid, and ethanol. The acids lower crop pH to between 4.0 and 5.0 in alfalfa and grass silages and below 4.0 in corn silage.

Both the low $\mathrm{pH}$ and the acids are beneficial in preserving the crop. The principal bacterial competitors of the lactic acid bacteria under anaerobic conditions (enterobacteria, clostridia and bacilli) are all inhibited by achieving a sufficiently low pH. Once pH drops below 4.5 to 5.0 , enterobacteria and bacilli will be inhibited, and enterobacterial populations will usually drop below detectable levels within a few days after the $\mathrm{pH}$ is below 5.0. Counts of bacilli do not drop as quickly due to their ability to form spores, and standard enumeration techniques for bacilli in silage only measure spores. The exact $\mathrm{pH}$ to inhibit these groups does vary by crop and DM content in addition to the bacterial strains present. However, fermentation by the lactic acid bacteria usually takes silage $\mathrm{pH}$ to a level that inhibits these bacteria. So often we forget about these two groups unless we have a high acetic acid silage that is feeding poorly.

Clostridia can grow at lower $\mathrm{pH}$ values than the enterobacteria and bacilli, making them more difficult to control. As a consequence, it is of greater importance to understand the interaction of $\mathrm{pH}, \mathrm{DM}$ content and crop. Figure 1 shows the critical pH to inhibit $C$. tyrobutyricum, one of the principal fermenters of lactic acid to butyric acid. Ensiling a wet crop requires a lower $\mathrm{pH}$ to prevent clostridial growth. Grasses including corn have a higher water activity at a given DM content compared with legumes like alfalfa so that fermentation to a lower $\mathrm{pH}$ is required in grasses to prevent clostridial growth. Because it is easy to obtain a silage $\mathrm{pH}$ below 4.0 in corn, clostridial silage is uncommon in corn silage. In alfalfa and grass silages, it is more difficult to achieve a sufficiently low $\mathrm{pH}$ to inhibit clostridia. Thus in these crops the producer may need to wilt the crop to a high DM content (reducing the amount of fermentation needed to inhibit the clostridia) or use an additive to achieve a lower $\mathrm{pH}$ than is possible by natural fermentation.

The lactic and acetic acids together with low $\mathrm{pH}$ are inhibitors of various aerobic microorganisms. Low $\mathrm{pH}$ is normally thought to inhibit Listeria monocytogenes, the cause of listeriosis. However, Donald et al. (1995) observed listeria at $\mathrm{pH} 4.2$ in a grass silage with restricted fermentation, suggesting that the fermentation acids in addition to low $\mathrm{pH}$ are critical to reducing their population. Lactic acid is an inhibitor of acetic acid bacteria, which can begin the spoilage of corn silage (Courtin \& Spoelstra, 1990). It is possible that the reason acetic acid bacteria have only been reported in corn silage is that whole-plant corn is low in buffering capacity so that relatively little lactic acid is required to lower $\mathrm{pH}$ to a stable value below 4.0.

The volatile fatty acids are good inhibitors of yeasts and molds (Moon, 1983). Acetic acid is not as good an inhibitor as the longer chain fatty acids, but more effective than lactic acid. The effect of acetic acid on fungal growth is related to the undissociated concentration in solution. Thus a given concentration of acetic acid becomes more inhibitory to yeasts and molds as silage $\mathrm{pH}$ decreases.

Unfortunately, lactic acid bacterial fermentation rarely lowers $\mathrm{pH}$ sufficiently and produces enough acetic acid to prevent yeasts and molds from growing in silage. Many yeasts and molds as well as acetic acid bacteria will grow at

Table 2 - Typical lactic acid bacterial fermentations

\begin{tabular}{ll}
\hline Group & \multicolumn{1}{c}{ Fermentation } \\
\hline Homofermenter/Fac. Hetero. & 1 6-C Sugar $\rightarrow 2$ Lactic acid \\
Facultative Heterofermenter & 1 5-C Sugar $\rightarrow 1$ Lactic acid +1 Acetic acid \\
Heterofermenter & 1 6-C Sugar $\rightarrow 1$ Lactic acid +1 Acetic acid $+\mathrm{CO}_{2}$ \\
& 1 6-C Sugar $\rightarrow 1$ Lactic acid +1 Ethanol $+\mathrm{CO}_{2}$ \\
& 1 5-C Sugar $\rightarrow 1$ Lactic acid +1 Acetic acid \\
& 1 Lactic acid $\rightarrow 1$ Acetic acid $+\mathrm{CO}_{2}$ \\
\hline
\end{tabular}




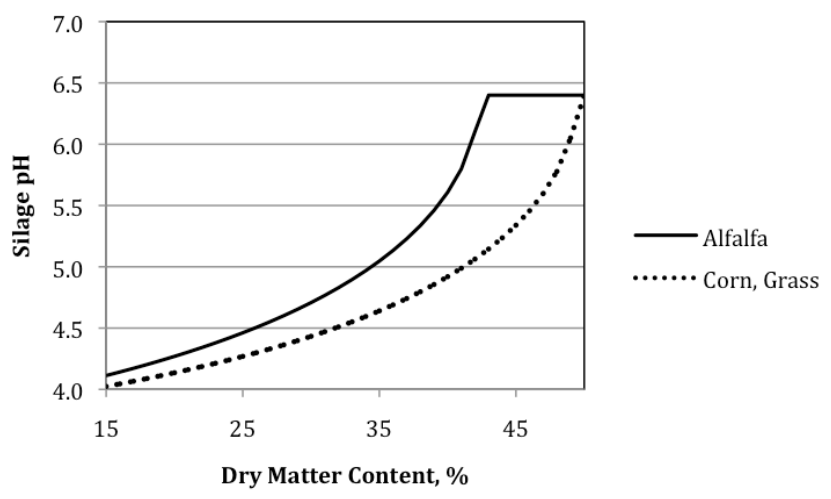

Figure 1 - Critical pH to stop clostridial growth, based on Leibensperger \& Pitt (1987).

$\mathrm{pH}$ 3.5, well below normal silage pHs. Once oxygen is present, yeasts, molds and acetic acid bacteria can begin to grow on silage, using fermentation products and residual sugars in the silage and producing carbon dioxide, water and heat. As fermentation products are used up, silage $\mathrm{pH}$ rises. Once the $\mathrm{pH}$ is above 4.5 , a wide variety of other aerobic microorganisms can grow, spoiling the silage more and causing even greater heating of the silage. All of these losses are of the most digestible parts of the silage. This spoilage loss can only be prevented by keeping oxygen out of the silo and minimizing silage expose to oxygen while emptying the silo.

In summary, good preservation and stabilization of the crop in the silo is due to the combination of an anaerobic environment and the growth of lactic acid bacteria. The lactic acid bacterial fermentation produces acids that lower $\mathrm{pH}$ and stop the growth of detrimental anaerobic microorganisms. The low $\mathrm{pH}$ and acids help slow, but usually do not stop, the growth of aerobic spoilage microorganisms. The anaerobic environment promotes the growth of lactic acid bacteria. More importantly, anaerobic conditions are the only way to prevent the growth of yeasts, molds and aerobic bacteria that spoil and heat silage.

\section{Bacterial inoculants}

Inoculants are the most common silage additives. These products contain lactic acid bacteria to supplement the lactic acid bacteria naturally on the crop and help ensure a consistent fermentation in the silo. The standard type of silage inoculant that has been marketed for several decades contains one or more homofermentative species of lactic acid bacteria. Lactobacillus plantarum is the most common species used. However, Lactobacillus casei, various Pediococcus species and Enterococcus faecium are other species that may be included in these products. These strains have generally been selected for rapid growth and domination of silage fermentation. Recently, a heterofermentative species, Lactobacillus buchneri, has begun to be marketed alone or in combination with homofermentative species. The entry of the L. buchneri products has made it more difficult to know what, if any, inoculant should be used in making silage.

The differences in the fermentation products between the homofermentative species and a heterofermenter like L. buchneri have already been discussed (Table 2). The homofermentative strains should produce a fermentation high in lactic acid whereas $L$. buchneri will produce a mix of products. The L. buchneri strains used in inoculants have an advantage over many other heterofermentative strains, the ability to ferment lactic acid to acetic acid. This should result in a fermentation higher in acetic acid than those produced by other heterofermentative strains.

Generally, lactic acid is the preferred end product of fermentation in the silo. Lactic acid is a stronger acid ( $\mathrm{pK}_{\mathrm{a}}$ 3.86) than acetic ( $\mathrm{pK}_{\mathrm{a}}$ 4.76). Thus one would expect homofermentative inoculants to lower silage $\mathrm{pH}$ more rapidly and attain a lower final $\mathrm{pH}$ compared to the $\mathrm{pH}$ of untreated or L. buchneri-treated silage. The rapid drop to a low $\mathrm{pH}$ should reduce the activity of enterobacteria, clostridia and bacilli and their effects on silage quality. Homofermentative fermentation produces no $\mathrm{CO}_{2}$ and should therefore improve DM recovery from the silo compared to untreated silage. Rumen bacteria ferment lactic acid whereas acetic acid is a product of rumen fermentation, and ethanol may be fermented in the rumen but can also be absorbed through the rumen wall without fermentation. So, there should be a small benefit to rumen microbial growth from producing lactic acid in the silo rather than other common end products. The only downside to lactic acid is that acetic acid is a better inhibitor of yeasts and molds. So, L. buchneri by producing acetic acid is more likely to improve aerobic stability than a homofermentative inoculant.

\section{Homofermentative inoculant performance}

There is an abundance of published research studies using various inoculants. This should form a basis for understanding how, when and where these products work. However, there are relatively few comparisons of a wide variety of commercial products within a given study, and all of these comparisons are on laboratory-scale silos. Evaluations of animal effects are generally limited to one or two products versus an untreated control.

Various scientists have summarized the published literature, and a general picture emerges of what to expect 
from homofermentative inoculants. In one of the largest surveys, Muck \& Kung (1997) reviewed over 230 trial comparisons (inoculated vs. untreated silage) published between 1990 and 1995. Homofermentative inoculants lowered $\mathrm{pH}$ and shifted fermentation toward lactic acid and away from acetic acid in approximately $60 \%$ of the cases they summarized. These inoculants were most often effective in grass and alfalfa silages. They succeeded in changing silage fermentation less than half the time in corn silage and approximately one-third the time in whole-crop small grain silages compared to untreated silages.

There are a number of reasons why a product might not change fermentation. First, a product might be ineffective or mishandled or misapplied. A significant number of studies never measured the number of lactic acid bacteria in the product they used to make sure that the product contained the number of bacteria claimed on the package. Second, it might be hard to improve upon the unassisted fermentation. Corn and whole-crop small grain silages typically have fermentations that are naturally high in lactic-to-acetic acid ratio and reach a low $\mathrm{pH}$. If a crop is low in sugar at ensiling, there may be little opportunity for an inoculant to significantly affect silage quality. In both of these situations, the inoculated silage may reach a stable $\mathrm{pH}$ sooner, but little difference may be observed between treated and untreated silages at silo opening. Finally, the epiphytic population of lactic acid bacteria may be so high that the inoculant bacteria never dominate the fermentation. We applied an inoculant at various levels to alfalfa (Muck, 1989). When the inoculant was added at a rate that was at least $10 \%$ of the epiphytic population, the inoculant always improved fermentation. When the inoculant was applied at less than $1 \%$ of the epiphytic population, the inoculant produced no significant changes in fermentation. The problem with using an inoculant at ensiling is that we do not know what the epiphytic population is until at best 2 or 3 days after ensiling.

The shift in fermentation to lactic acid does not directly benefit the farmer. However, two substantial benefits of homofermentative inoculants have been seen. The survey of Muck \& Kung (1997) found that DM recovery was improved in $38 \%$ of the studies with an average increase of 6 percentage points in the cases with a significant increase. This is more than can be explained by lactic acid bacterial fermentation alone and suggests reduced spoilage in inoculated silages. Averaging over all conditions whether the inoculant succeeds or not, one can expect a homofermentative inoculant to provide a 2 to 3 percentage unit improvement in DM recovery from the silo.
Improvements in animal performance have also been observed. In approximately half the studies surveyed, inoculants improved gain in growing cattle and milk production in lactating cows (Kung \& Muck, 1997). When the inoculated silage produced a positive effect, the average increase in daily gain (5\%) was somewhat higher than the increase in milk production (3\%). The causes for these increases in performance are difficult to explain. Intake of silage was improved in only a fifth of the trials so that the performance boost appears to be related more to the efficiency of silage utilization by livestock rather than the quantity of silage consumed. Recently, we compared a wide range of inoculants on alfalfa silage and measured effects on ruminal in vitro gas and volatile fatty acid production (Muck et al., 2007). Intriguingly, some inoculants reduced gas production and acetate-topropionate ratio compared to those of the untreated silages. By difference, these results suggest an improvement in rumen microbial growth on some inoculated silages. The degree of change varied by inoculant, but in vitro effects were observed even when the inoculants had little effect on silage fermentation, an observation in a number of animal trials (Weinberg \& Muck, 1996). More research is needed to discover and explain the observed effects. However, we have evidence that a homofermentative inoculant can increase microbial biomass production during in vitro rumen fermentation (Table 3 ) and that the level of increase is of an order that could explain milk production trial effects. If the in vitro effects can be verified by in vivo trials, there still remain the questions of why an inoculated silage would increase rumen microbial growth. While many questions remain, we are getting closer to understanding how an inoculant, which is marketed to ensure a good fermentation in the silo, can have a significant effect on livestock.

A final issue is aerobic stability. While homofermentative inoculants are often marketed as improving aerobic stability, the observed effects in studies have been small and mixed (Muck \& Kung, 1997). There were significant positive effects in less than a third of the studies and significant negative effects in approximately a third of the studies. Most of the positive effects were in hay crop silages whereas as the negative effects were largely in corn and whole-crop small grain silages. Does this make sense? Actually, yes. Small shifts in aerobic stability would be predicted by the changes that homofermentative inoculants make in silage fermentation. A lower $\mathrm{pH}$ makes silage acids more inhibitory to yeasts, the usual initiators of heating in silage. Lactic acid is less inhibitory to yeasts 
Table 3 - Products of 9-h in vitro ruminal fermentations averaged across three trials with alfalfa silage and one trial with corn silage (Contreras-Govea et al., 2009)

\begin{tabular}{|c|c|c|c|c|c|}
\hline & \multicolumn{3}{|c|}{ Treatment } & \multirow[b]{2}{*}{ Range } & \multirow[b]{2}{*}{$\operatorname{LSD}(P<0.05)$} \\
\hline & Control & $\mathrm{MTD} / 1^{1}$ & FA & & \\
\hline Gas, $\mathrm{mL} \mathrm{g}^{-1} \mathrm{DM}$ & 156 & 152 & 155 & $133-169$ & NS \\
\hline Acetate, mM & 27.2 & 28.2 & 29.5 & $22.1-36.3$ & NS \\
\hline Propionate, mM & 10.6 & 10.6 & 10.0 & $8.1-14.5$ & NS \\
\hline Butyrate, mM & 4.7 & 4.7 & 4.4 & 3.4-6.5 & NS \\
\hline Total VFA, mM & 42.6 & 43.5 & 43.9 & $37.3-48.8$ & NS \\
\hline MBY, mg $100 \mathrm{mg}^{-1} \mathrm{TD}$ & 43.9 & 47.2 & 47.5 & $41.8-57.5$ & 2.80 \\
\hline
\end{tabular}

${ }^{1}$ MTD/1, L. plantarum MTD/1; FA, formic acid; VFA, volatile fatty acids; NAN, non-ammonia nitrogen; MBY, microbial biomass yield.

than acetic acid. In alfalfa silage, inoculants often produce a 0.2 to 0.3 unit reduction in $\mathrm{pH}$ compared to an untreated silage, and this reduction in $\mathrm{pH}$ may more than offset the shift to lactic acid, increasing aerobic stability. In corn silage, inoculants often have no effect on $\mathrm{pH}$ but do shift fermentation away from acetic to lactic acid, having negative effects on aerobic stability (Muck, 2004).

\section{Lactobacillus buchneri performance}

This species was introduced to address the problem of aerobic stability. The primary purpose of this microorganism is to increase the amount of acetic acid and as a consequence decrease the level of yeasts in a silage.

The meta-analysis of Kleinschmit \& Kung (2006) that summarized 43 experiments provides a good overview of the effects of $L$. buchneri on silage quality (Table 4 ). These inoculants reduced the amount of lactic acid and increased the amount of acetic acid in silage with a subsequent increase in $\mathrm{pH}$ compared with that observed in untreated silages. Inoculated silages had reduced yeast counts, particularly in corn silage, and increased aerobic stability. In corn silage, there appeared to be a dose response over a wide range of parameters. Inoculants supplying more than $100,000 \mathrm{cfu} / \mathrm{g}$ crop had a larger effect on fermentation and aerobic stability than inoculants applied at 100,000 cfu or less per g crop. In grass and whole-crop small-grain silages, the dose response was much smaller and only significant for acetic acid and aerobic stability. The meta-analysis also indicated that there is a cost in DM recovery of about 1 percentage point. This is due to one mole of $\mathrm{CO}_{2}$ being released for every mole of acetic acid produced (Table 2).

One area not addressed by the meta-analysis was animal performance because there were an insufficient number of published studies at that time. There are concerns that high acetic acid levels ( $>50 \mathrm{~g} / \mathrm{kg} \mathrm{DM}$ ), as have been observed in some $L$. buchneri-treated silages, might reduce intake. However, the five available studies at that time did not show any negative effect of acetic acid from $L$. buchneri on intake (Kleinschmit \& Kung, 2006). One study with alfalfa reported a small but statistically significant increase in milk production $(0.8 \mathrm{~kg}$ milk/cow $/ \mathrm{d})$, but otherwise animal performance has not been different from that on untreated silage. Few animal trials have been published since this meta-analysis so we do not have a complete understanding of how L. buchneri-treated silage affects animal performance. At this point, it appears that $L$. buchneri has little effect on intake and performance beyond keeping silage cool.

Another issue with $L$. buchneri is the speed with which these bacteria work in the silo. With homofermentative inoculants, companies have chosen strains that grow

Table 4 - Effects of Lactobacillus buchneri on silage characteristics (Kleinschmit \& Kung, 2006)

\begin{tabular}{|c|c|c|c|c|c|c|}
\hline \multirow[b]{2}{*}{ Item } & \multicolumn{3}{|c|}{ Corn silage } & \multicolumn{3}{|c|}{ Grass and Small-grain silage } \\
\hline & $\mathrm{LB}^{\mathrm{a}}$ & LB1 & LB2 & LB0 & LB1 & LB2 \\
\hline Dry matter, \% & 30.7 & 30.7 & 30.7 & 31.8 & 31.7 & 32.3 \\
\hline $\mathrm{pH}$ & 3.70 & 3.75 & 3.88 & 4.19 & 4.41 & 4.41 \\
\hline Lactate, g/kg DM & 65.9 & 58.7 & 47.9 & 73.2 & 30.1 & 27.6 \\
\hline Acetate, g/kg DM & 21.8 & 26.3 & 38.9 & 13.8 & 35.9 & 43.1 \\
\hline Ethanol, g/kg DM & 16.2 & 15.8 & 14.7 & 4.4 & 8.6 & 8.4 \\
\hline DM Recovery, \% & 95.5 & 95.5 & 94.5 & 96.6 & 94.8 & 95.3 \\
\hline Yeasts, log cfu/g & 4.18 & 3.10 & 1.88 & 0.95 & 0.56 & 0.56 \\
\hline Aerobic stability, h & 25 & 35 & 503 & 206 & 226 & 245 \\
\hline
\end{tabular}

${ }^{a}$ LB0, untreated; LB1, L. buchneri applied at $\leq 100,000 \mathrm{cfu} / \mathrm{g}$ crop; LB2, L. buchneri at $>100,000 \mathrm{cfu} / \mathrm{g}$. 
rapidly and dominate the fermentation. The current strains of $L$. buchneri are rather slow. So other lactic acid bacteria may do the primary work of fermentation during the first few days of ensiling, but $L$. buchneri can survive and grow under acid conditions that inhibit other lactic acid bacteria. Thus after active fermentation is finished, the L. buchneri strains slowly convert lactic to acetic acid. This means that their effect on aerobic stability may take a while to be observed, typically 45 to $60 \mathrm{~d}$.

\section{Combination inoculant performance}

Combination inoculants, ones containing L. buchneri plus homofermentative strains, are the most recent additions to the marketplace. These products seek to gain the best of both types of inoculants - an initial fermentation controlled by homofermentative strains giving good DM recovery and animal performance and a later fermentation of some of the lactic acid to acetic acid by $L$. buchneri providing improved aerobic stability. One combination product has an additional feature, a L. buchneri strain that also produces a ferulic acid esterase enzyme that should help break the linkages between lignin and the carbohydrates in grass cell walls, potentially improving fiber digestibility.

Most published research trials on this approach have studied these products in laboratory-scale silos. Trials where silos were opened at several times within the first week of ensiling show that the homofermentative portion can increase the speed of fermentation relative to untreated silage. At longer ensiling times ( $>50$ days), acetic acid and aerobic stability are increased relative to those in untreated silage (Table 5), indicating that the L. buchneri portion is doing its job. Abstracts on the combination product containing the $L$. buchneri strain that produces ferulic acid esterase show some improvement in in situ neutral detergent fiber digestibility, with increases ranging from 0 to $70 \mathrm{~g} / \mathrm{kg}$ fiber depending on the trial. The biggest question mark that remains is whether any or all of these combination products can increase animal productivity. Currently we are limited to data reported by manufacturers of the products.

Summary of how inoculants control silage microbial activity

The homofermentative inoculants have a different role than $L$. buchneri products. The homofermentative inoculants are intended to minimize the activity of other microorganisms early in fermentation such as the enterobacteria and bacilli. If clostridial populations are high at ensiling, these products could also reduce negative effects from clostridia during active lactic acid bacterial fermentation. Homofermentative inoculants by reducing final $\mathrm{pH}$ could have a role in preventing clostridial development later in storage, i.e., the fermentation of lactic acid to butyric. However, this effect would be expected to occur in only a limited number of cases - ones where the natural fermentation just misses in reducing $\mathrm{pH}$ sufficiently to inhibit clostridia but where the extra reduction in $\mathrm{pH}$ by the inoculant does inhibit them.

In contrast, the $L$. buchneri inoculants are aimed at controlling the development of aerobic spoilage microorganisms when the silage is reintroduced to oxygen, ideally not until the silage is being fed. These inoculants produce high levels of acetic acid that can suppress yeast and mold populations. In most silages, yeasts are the initiators of aerobic deterioration because of their ability to grow relatively rapidly at low $\mathrm{pH}$. This inoculant approach has been effective in delaying aerobic microbial growth on silage, but it normally does not completely inhibit yeast growth. Furthermore, it must be remembered that aerobic deterioration in corn silage and possibly other $\mathrm{C} 4$ grasses may be initiated by acetic acid bacteria that grow at low $\mathrm{pH}$, are more tolerant of high acetic acid concentrations than yeasts, and can utilize acetic acid as a substrate.

Table 5 - Silage characteristics after 5 days aerobic exposure when treated with L. buchneri, L. plantarum or both species (Filya, 2003)

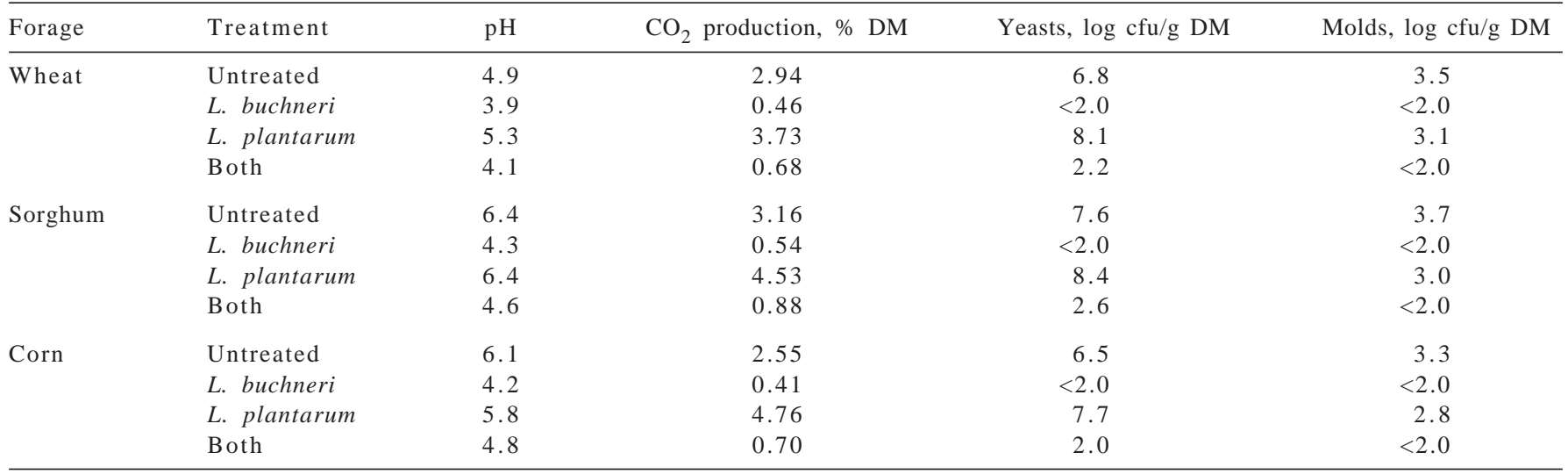




\section{Conclusions}

Ensiling preserves a crop by controlling microbial activity through a combination of an anaerobic environment and a natural fermentation of sugars by lactic acid bacteria on the crop. Two fermentation products (lactic and acetic acids) and the resulting low $\mathrm{pH}$ primarily suppress the growth of other anaerobic microorganisms. The fermentation can also inhibit yeasts, molds and aerobic bacteria, but the anaerobic environment is essential to preventing most of the spoilage microorganisms from growing.

Inoculants, products supplementing the crop with selected strains of lactic acid bacteria, have become the dominant additives for making silage. Homofermentative strains help guarantee a rapid suppression of other anaerobic microorganisms early in storage, increase dry matter recovery and have improved animal performance by means that we do not fully understand. These inoculants may lower $\mathrm{pH}$ sufficiently to prevent clostridial growth in limited cases where the epiphytic lactic acid bacterial fermentation falls just short of suppression. Inoculants containing Lactobacillus buchneri, a heterofermentative species capable of fermenting lactic acid to acetic, are recent additives. The added acetic acid inhibits yeast and mold growth, increasing aerobic stability of silages at feeding. Acetic acid production does result in additional $\mathrm{CO}_{2}$ loss, reducing dry matter recovery approximately 1 percentage point on average. Overall, inoculants are additives that can be used to improve silage quality when used appropriately together with good silage management.

\section{References}

CONDON, S. Responses of lactic acid bacteria to oxygen. FEMS Microbiology Reviews, v.46, p.267-280, 1987.

CONTRERAS-GOVEA, F.E.; MUCK, R.E.; BRODERICK, G.A. et al. Lactobacillus plantarum MTD/1, its impact on silage and in vitro rumen fermentation. In: INTERNATIONAL SILAGE CONFERENCE, 15., 2009, Madison. Proceedings... Madison: University of Wisconsin, 2009. p.57-58.
COURTIN, M.G.; SPOELSTRA, S.F. A simulation model of the microbiological and chemical changes accompanying the initial stage of aerobic deterioration of silage. Grass and Forage Science, v.45, p.153-165, 1990.

DONALD, A.S.; FENLON, D.R.; SEDDON, B. The relationships between ecophysiology, indigenous microflora and growth of Listeria monocytogenes in grass silage. Journal of Applied Bacteriology, v.79, p.141-148, 1995.

FILYA, I. The effect of Lactobacillus buchneri, with or without homofermentative lactic acid bacteria, on the fermentation, aerobic stability and ruminal degradability of wheat, sorghum and maize silages. Journal of Applied Microbiology, v.95, p.1080-1086, 2003.

GOLLOP, N.; ZAKIN, V.; WEINBERG, Z.G. Antibacterial activity of lactic acid bacteria included in inoculants for silage and in silages treated with these inoculants. Journal of Applied Microbiology, v.98, p.662-666, 2005.

KLEINSCHMIT, D.H.; KUNG JR., L. A meta-analysis of the effects of Lactobacillus buchneri on the fermentation and aerobic stability of corn and grass and small-grain silages. Journal of Dairy Science, v.89, p.4005-4013, 2006.

KUNG, JR., L.; MUCK, R.E. Animal response to silage additives. In: Silage: field to feedbunk. Ithaca: Northeast Regional Agricultural Engineering Service, 1997. p.200-210.

LEIBENSPERGER, R.Y.; PITT, R.E. A model of clostridial dominance in ensilage. Grass and Forage Science, v.42, p.297-317, 1987.

McDONALD, P.; HENDERSON, A.R.; HERON, S.J.E. The biochemistry of silage. 2.ed. Marlow: Chalcombe Publications, 1991. 340p.

MOON, N.J. Inhibition of the growth of acid tolerant yeasts by acetate, lactate and propionate and their synergistic mixtures. Journal of Applied Bacteriology, v.55, p.454460, 1983.

MUCK, R.E. Effect of inoculation level on alfalfa silage quality. Transactions of the ASAE, v.32, p.1153-1158, 1989.

MUCK, R.E. Effects of corn silage inoculants on aerobic stability. Transactions of the ASAE, v.47, n.4, p.1011-1016, 2004.

MUCK, R.E.; KUNG JR., L. Effects of silage additives on ensiling. In: Silage: field to feedbunk. Ithaca: Northeast Regional Agricultural Engineering Service, 1997. p.187-199.

MUCK, R.E.; PITT, R.E. Aerobic deterioration in corn silage relative to the silo face. Transactions of the ASAE, v.37, n.3, p.735743, 1994.

MUCK, R.E.; FILYA, I.; CONTRERAS-GOVEA, F.E. Inoculant effects on alfalfa silage: In vitro gas and volatile fatty acid production. Journal of Dairy Science, v.90, n.11, p.51155125, 2007.

PAHLOW, G.; MUCK, R.E.; DRIEHUIS, F. et al. Microbiology of ensiling. In: BUXTON, D.R.; MUCK, R.E.; HARRISON, J.H. (Eds.) Silage science and technology. Madison: American Society of Agronomy, Crop Science Society of America, Soil Science Society of America, 2003. p.31-93.

WEINBERG, Z.G.; MUCK, R.E. New trends and opportunities in the development and use of inoculants for silage. FEMS Microbiology Reviews, v.19, n.1, p.53-68, 1996. 